\title{
Correlation Between Emotional and Eye-Hand Coordination Ability Towards Passing Ability in Volleyball
}

\author{
Tjung Hauw $\operatorname{Sin}^{1 *}$ and Imam Prasetia ${ }^{2}$ \\ ${ }^{1,2}$ Dep. of Coaching, Faculty of Sport Science, Universitas Negeri Padang, Padang, Indonesia \\ *Corresponding author.Email: thsin@konselor.org
}

\begin{abstract}
The problem in this study is the lack of passing ability on volleyball in class X students of Adabiah Padang High School, this study aims to determine the correlation between emotional and eye-hand coordination to the passing ability of volleyball on class X students of Adabiah Padang High School. This research is a correlational type, the study population was 93 people, and the sample was taken by random sampling technique, the sample in this study were 60 students. The test used was a Likert scale questionnaire, a tennis ball throwing test, and the AAHPER face pass wall-volley test. The data analysis technique used is simple correlation analysis and multiple correlation. Research Results: There is a correlation between emotional and passing ability on volleyball by $\mathrm{r}_{\text {count }}(0.453)>\mathrm{r}_{\text {table }}$ (0.254). Hand-eye coordination provides a correlation to the passing ability of volleyball by $r$ count $(0.582)>r$ table (0.254). Then, emotional and eye-hand coordination together provide a correlation to the passing ability $\mathrm{r}$ count $(0.577)>\mathrm{r}_{\text {table }}(0.254)$.
\end{abstract}

Keywords: emotional, hand-eye coordination, passing, volleyball

\section{INTRODUCTION}

In the world of sports, there are various kinds of sports, one of which is the volleyball branch. The volleyball game can be used as a means to educate because volleyball sports can form a sporty, honest person, cooperation, responsibility, all of which are educational values that can be instilled. Therefore, volleyball is used as one of the material which is always included in the physical sports education subject matter.

Sports activities are many contributing factors that influence to achievements, such as physical condition, techniques, not tick, and mental (Soniawan, 2018 ). In volleyball, besides having good physical, technical, tactic and mental conditions, good technical mastery is also needed for the athlete, because without good technical mastery, an athlete cannot realize his achievements.

By providing learning that refers to the 2013 curriculum in high school, it is expected that the learning process can run well. In addition, the teacher must understand the student's situation, so the teacher must know that the material being taught is in accordance with the student's condition. In the volleyball game there are some basic techniques namely service, passing, smash and block. The basic technique is the most important thing in a branch of volleyball.

Because the basic technique will determine how to do a good basic movement, the success of doing the basic technique will also determine the success in playing a volleyball game. Passing means passing or passing, this technique is a basic technique that is quite difficult and is used in volleyball games. Similarly, in teaching physical education, mastery of passing both passing under or passing must be controlled by the student. Because it will determine how students play in the game of volleyball, therefore good reception passes are the start of smash success and the game will run well too.

For this passing technique to be successful and smooth, good coordination of body movements such as hand-eye coordination is needed, this hand-eye coordination is needed so that the ball and hand allowances are fitted, and the ball can play in the direction specified by the player. In addition, the level of emotional intelligence of students in passing movements is also needed because coordination of body movements will not be perfect if there is no ability to control students' emotions.

However, based on the results of observations conducted in the field, many students are not competent in passing over. Perhaps this is due to the lack of 
coordination of the hand movements of the students and the large number of students who do not like volleyball. Therefore the material taught by the teacher is not realized correctly and finally, not all students can make the passing movement correctly.

\section{RESEARCH METHODS}

This research is a type of correlational research. The study was conducted at Padang Adabiah High School. The population in this study amounted to 93 students of class X. Furthermore, the research sample consisted of 60 students of class $\mathrm{X}$ with a sampling technique that is random sampling, determining samples randomly in the population so that all subjects were considered equal. As the independent variables in this study are emotional and eye-hand coordination, while the Serikat variable is the passing ability of volleyball. Data collection techniques were carried out on the sample by using a Likert scale questionnaire to measure students 'emotions, whereas to measure students' eyehand coordination power using the tennis ball throwing test, and to measure the passing ability of a volleyball by using AAHPER face pass wall-volley test, (Winarno, 2006 ). The data analysis technique used is using a simple correlation formula and multiple correlation. To meet the requirements of the assumptions, a normality test is performed to determine whether the data obtained is normally distributed or not

\section{RESULTS AND DISCUSSION Data Description \\ 1). Emotional}

Based on research data for students' emotional scores obtained the highest score of 229 and the lowest score of 140. From the analysis of the data obtained an average price ( mean ) of 160, 3 and the standard deviation (standard deviation) of 25.8. The following can be seen in the histogram below.

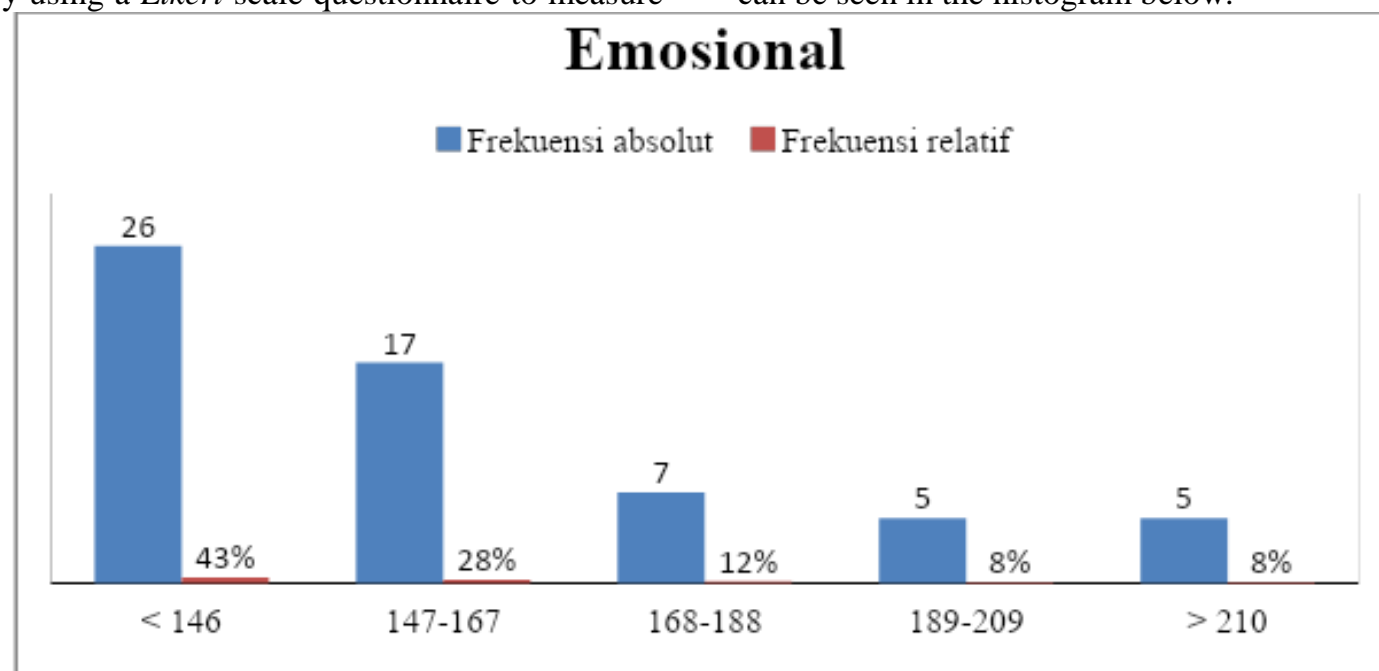

Figure 1. Emotional Frequency Histogram for Class X Students at Adabiah Padang High School

60 male samples that have a speed of reaction include: 26 people $(43 \%)$ have an emotional range of $<146$ are in the category of very less, 17 people $(28 \%)$ have an emotional range of (147-167) are in the category of lacking, 7 people $(12 \%)$ have emotional ranges between (168-188) are in the moderate category. 5 people $(8 \%)$ have emotional ranged (189-209) in the less category. 5 people $(8 \%)$ have emotional ranges between $(>210)$ are in the excellent category.

\section{2). Eye-Hand Coordination}

Based on research data for student eye-hand coordination a maximum score of 17 times was obtained and a minimum score of 8 times. From the analysis of the data obtained an average value ( mean ) of 13,82 and the standard deviation (standard deviation) of 1.79 . The following can be seen in the Histogram image below. 


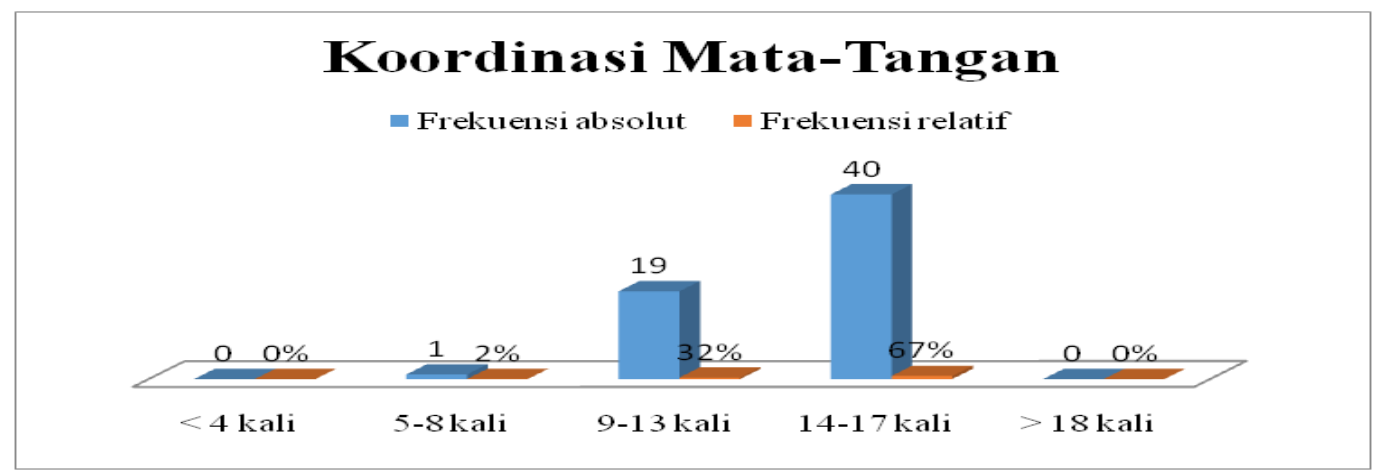

Figure 2. Histogram Frequency of Eye-Hand Coordination in Class X Students of Adabiah Padang High School

Based on the data contained in the image of the stem histogram, the explanation can be given as follows. Of the 60 samples who had eye-hand coordination, among others: 1 person (2\%) had eye-hand coordination ranging between (5-8 times) in the less category, 19 people $(32 \%)$ had eye-hand coordination ranging between (9-13 times) are in the sufficient category, 40 people $(67 \%)$ have eye-hand coordination ranging from (14-17 times) in the good category, while eye-hand coordination is in the excellent category and very little is not available ( $0 \%$ ) owned by students.

\section{3). Upper Passing Ability (Y)}

Based on research data for the score of passing ability on volleyball students obtained the highest score of 38 and the lowest score of 20. From the analysis of the data revealed an average score ( mean ) of 26, 82 and standard deviation (standard deviation) of 6.47. The following can be seen in the Histogram image below

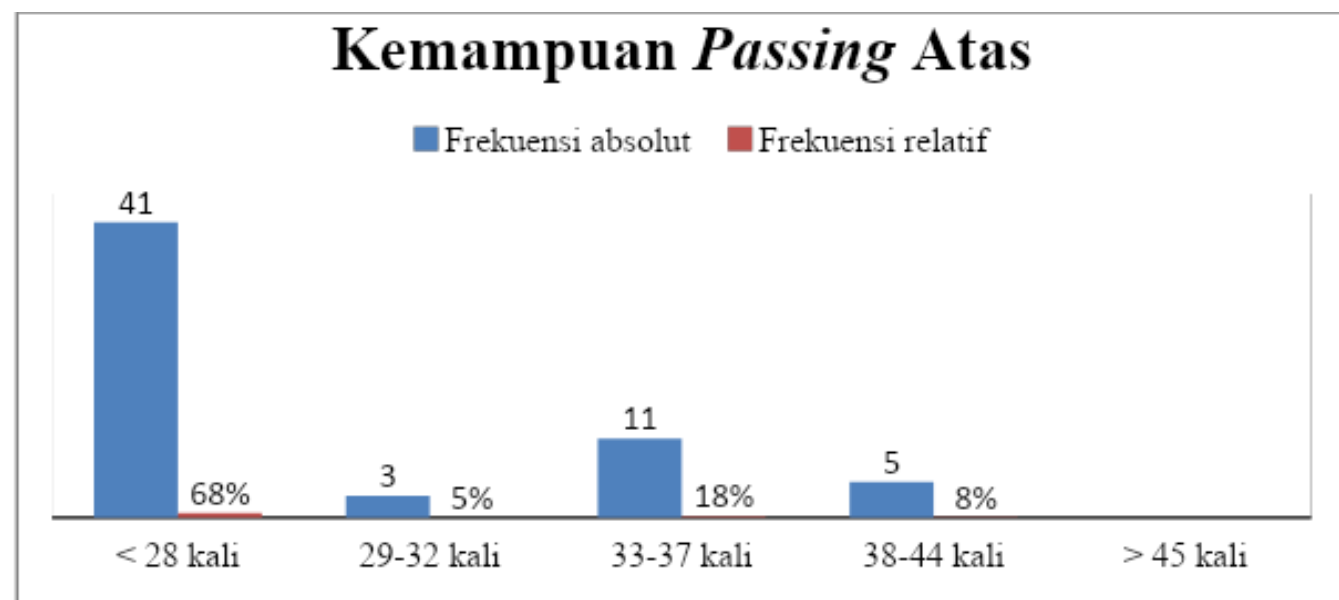

Figure 3: Histogram Frequency of Passing Ability for Volleyball Adabiah Padang High School Students

Based on the calculations listed on the Histogram on the previous page of 60 students who have the ability to pass, among others: 41 people $(68 \%)$ have the ability to pass the range between $(<28)$ are in the category of very less, 3 people $(5 \%)$ have the upper passing ability ranges between (29-32) are in the less category, 11 people $(18 \%)$ have the upper passing ability ranging between (33-37) are in the sufficient category, 5 people $(8 \%)$ have the upper passing ability ranging between ( $38-44)$ is in the good category. Whereas in the excellent category there is nothing $(0 \%)$ owned by students.

\section{Hypothesis Testing}

\section{a. Correlation between $X_{1}$ and $Y$}

The relationship between emotional $\left(\mathrm{X}_{1}\right)$ to the ability to pass over (Y). To find out the correlation, first, a simple correlation analysis is performed. From the results of the statistical analysis conducted, the $r_{\text {count }}$ is 0.453 for students. while $r_{\text {table }}$ in the level of $\alpha=0.05$ is 0.254 , so $r_{\text {count }}>r_{\text {table }}$. This means that there is a relationship between emotional and passing ability on volleyball in class X students of Adabiah Padang High School. Whereas to test the significant correlation coefficient between emotional and the ability to pass 


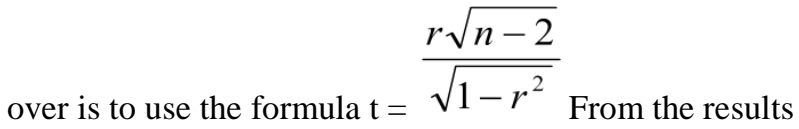
of the statistical analysis conducted, it was obtained tcount $=3,87$ for students. While $\mathrm{t}$ table $=1,67$, because $\mathrm{t}$ arithmetic $>\mathrm{T}_{\text {tab, it }}$ can be concluded that there is a significant relationship between $\mathrm{X}_{1}$ to $\mathrm{Y}$ in class $\mathrm{X}$ students of Adabiah Padang High School.

\section{b. Correlation between $\mathrm{X}_{2}$ and $\mathrm{Y}$}

The relationship between eye-hand coordination $\left(\mathrm{X}_{2}\right)$ with the ability to pass over $(\mathrm{Y})$. To find out this relationship, first, a simple correlation analysis is performed. From the results of the statistical analysis conducted, the $r$ count was 0.582 for the students. While $r$ table in the level of $\alpha=0,05$ is 0.254 , so $r_{\text {count }}>r_{\text {table }}$. This means that there is a relationship between eye-hand coordination and the passing ability of volleyball for class X students of Adabiah Padang High School. Meanwhile, to test the significant correlation coefficient between eye-hand coordination with the ability to pass

over is to use the formula $\mathrm{t}=. \frac{r \sqrt{n-2}}{\sqrt{1-r^{2}}}$

From the results of the statistical analysis conducted, it was obtained $t_{\text {count }}=5,45$ in male athletes. While $\mathrm{t}_{\mathrm{tab}}=1.67$, because $\mathrm{t}_{\text {arithmetic }}>$ from $\mathrm{t}$ tab, it can be concluded that there is a significant relationship between $\mathrm{X}_{1}$ and $\mathrm{Y}$ in class $\mathrm{X}$ students of Padang Adabiah High School.

\section{c. Correlation between $X_{1}$ and $X_{2}$ with $Y$}

The relationship between emotional $\left(\mathrm{X}_{1}\right)$ and eye-hand coordination $\left(\mathrm{X}_{2}\right)$ on the ability to pass over. To find out this relationship, first, a simple correlation analysis is performed. From the results of the statistical analysis conducted, the $r$ count is 0,65 for the students. While $r_{\text {table }}$ in the level of $\alpha=0,05$ is 0.254 , so $r_{\text {count }}$ > $r_{\text {table }}$. This means that there is a significant relationship between emotional and eye-hand coordination to the passing ability of volleyball in class $\mathrm{X}$ students of Adabiah Padang High School. Whereas to test the significant correlation coefficient between emotional and eye-hand coordination on passing ability is to use the formula $\mathrm{F}=\frac{R^{2} / K}{1-R^{2} / N-K-1}$. From the results of the statistical analysis, it was obtained that $\mathrm{F}$ count $=$ 20,87 for male athletes. While $F$ table $=3.16$, because $F$ count $>\mathrm{F}$ table, it can be concluded that there is a significant relationship between emotional $\left(\mathrm{X}_{1}\right)$ and eye-hand coordination $\left(\mathrm{X}_{2}\right)$ to the ability to pass over (Y) volleyball in class $\mathrm{X}$ high school students Adabiah Padang.
The results of the study prove that there is a relationship between emotional and passing ability of 0.453 . This means that this study proves that emotional variables are related to the passing ability of volleyball in class X students of Adabiah Padang High School. Emotional according to David, (2012: 245) is every activity or processing of thoughts, feelings, lusts for every great mental state or overflowing. This shows that emotional in the form of: a). Self-awareness, knowing how we feel at some time and using it to make our own decisions, has a real benchmark of our ability and selfconfidence; b). self-regulation, handling our emotions in such a way as to have a positive impact on the performance of tasks, be sensitive to conscience and be able to postpone pleasure before achieving a goal, and be able to recover from emotional pressure; c). Motivation uses the deepest desires to move and guide us towards our goals, help us take initiative and act very effectively, and to survive facing failure and frustration.

This means that students are able to control themselves in carrying out the passing techniques in order to produce good passing techniques so that students can feed the ball to a teammate well as well, and encourage themselves to continue to do exercises in forming a good top passing technique, and be able to survive or recover quickly when facing failure and frustration in passing the volleyball technique .

The results of the study prove that there is a relationship of eye-hand coordination on the ability to pass over the correlation coefficient of 0.582 . This means that the eye-hand coordination variable is related to the passing ability of club volleyball in class $\mathrm{X}$ students of Arabia Padang High School. Based on the results of research that has been done it is evident that eye-hand coordination provides a relationship to the passing ability of volleyball. This means that eye-hand coordination variables can provide a relationship to the passing ability of volleyball. Therefore the element of eye-hand coordination must be given to class $\mathrm{X}$ students of Adabiah Padang High School.

Eye-hand coordination must continue to be trained and improved through training programs that are arranged based on planned and systematic training programs. Irawadi (2011: 13) said that "The training program is a set of training activity plans arranged in such a way as a guide in practicing for a certain period of time and a certain goal". Thus it can be explained, that training programs that are planned and arranged in such a way based on training knowledge are very important in shaping the physical condition of volleyball athletes, especially in training eye-hand coordination to achieve maximum performance.

The results of the study prove that there is an emotional connection with eye-hand coordination 
together providing a relationship to the ability to passover with the Correlation Coefficient of 0, 65. This means that this study proves that there is a relationship between emotional variables with joint hand-eye coordination to the passing ability of volleyball in class $\mathrm{X}$ students of Adabiah Padang High School. Research shows that there is an emotional connection and eyehand coordination together towards the ability to pass over. This means that emotional variables with eye-hand coordination together are related to the passing ability of volleyball in class $\mathrm{X}$ students of Adabiah Padang High School.

From the above opinion when passing over to pass the ball to a teammate, the emotional element with eye-hand coordination provides a relationship to students, so that the player is able to make the passing over for the better. But this cannot be separated from the training process that has been arranged systematically and continuously. In addition, athletes must also have a strong motivation in him. According to Syafruddin (2012: 142 ) " motivation can be interpreted as an impulse or enthusiasm in a person to successfully do a job".

\section{CONCLUSIONS AND SUGGESTIONS}

Based on the results of data analysis and discussion, it can be concluded that there is a relationship between emotional and hand-eye coordination on the ability to pass over in class $\mathrm{X}$ students of Adabiah Padang High School.

\section{REFERENCES}

[1] Bompa, tudor, o. 2000. Total Training ForYoung Champion. Usa : Human Kinetik y Development.
[2] Daud, Firdaus. 2012. Pengaruh Kecerdasan Emosional (EQ) dan Motivasi Belajar terhadap Hasil Belajar Biologi Siswa SMA 3 Negeri Kota Palopo. Jurnal Pendidikan dan Pembelajaran. Vol 19. No 2, Oktober 2012. Hal 234-255.

[3] Djoko Pekik Irianto. 2002. Dasar Kepelatihan. Yogyakarta: FIKUNY.

[4] Edi Marheni, Apriyanti Rahmalia dan Rinia Nelavani. 2012.’Bullying Versus Tawuran (Studi Tentang Kematangan Emosional Siswa SMK Kota Padang)." Jurnal Penelitian Profesor. Nomor 4. Hlm. 1-77

[5] Goleman, Daniel. 1997. Kecerdasan emosional. Jakarta: PT Gramedia Pustka Utama

[6] Irawadi, Hendri. 2011. Kondisi Fisik Dan Pengukurannya. Padang:UNP Press.

[7] Irwanto, Edi. 2017. "Pengaruh Metode Resiprokal dan Latihan Drill Terhadap Peningkatan Keterampilan Teknik Dasar Bolavoli”. Jurnal Pendidikan Olahraga. Vol 6. No 1, Juni. Hal 1020.

[8] Ismaryati. 2009. Tes Dan Pengukuran Olahraga. Surakarta: UNS Press.

[9] Soniawan, V. Metode Bermain Berpengaruh Terhadap Kemampuan Long Passing Sepakbola.

[10] Sukadiyanto. 2002. Teori Dan Metodologi Melatih Fisik Petenis. Yogyakarta: FIKUNY

[11] Syafruddin. 2012. Permainan Bola Voli. Padang: UNP Press Padang.

[12] Winarno, M. E. 2006. Evaluasi Dalam Pendidikan Jasmani Dan Olahraga. Jakarta : Center For Human

Capacit 